\title{
The impact of social media access and anxiety among Indonesian society during covid-19 outbreak
}

\author{
Ifdil Ifdil $^{1}$, Berru Amalianita ${ }^{2 *}$, Rima Pratiwi Fadli ${ }^{2}$, Nilma Zola $^{2}$, Yola Eka Putri ${ }^{2}$ \\ ${ }^{1}$ Universitas Negeri Padang, Indonesia \\ ${ }^{2}$ Indonesian Institute for Caunseling Education and Theraphy, Indonesia \\ ${ }^{*}$ Corresponding author, ఏe-mail: berru@konselor.org
}

\begin{abstract}
The first cases of COVID-19 was reported in Indonesia on 2 March 2020. All caused global panic, fears, anxiety around the coronavirus have been especially amplified by social media. During coroan virus outbreak, disinformation and false reports have bombarded social media and stoked unfounded anxiety among Indonesian society. This research, therefore, aims to analyze the impact social media and anxiety level during COVID-19 outbreak in Indonesia. The procedure of this research is Indonesian citizens old were invited to participant online survey thought Survey Monkey platform. There are 1543 participant form aged 17 to 60 Year and form several province and region in Indonesia. The instrumen useing the DASS was to modify patients' anxiety. Data analyzed using JASP (Jeffrey's Amazing Statistics Program). The research showed that respondents anxiety in the very haviness category with the highest anxiety when the duration of social media access more than 6 hours in a day. The anxiety base of aspect in watching/reading have a higher, then Imagine and listening when access social media about corona virus among Indonesia society. Social media use is complex reading or watching lots of news about coronavirus has led to anxiety.
\end{abstract}

Keywords: Social media, anxiety, Indonesian society, covid-19 outbreak

How to Cite: Ifdil, I., Amalianita, B., Fadli, R., Zola, N., \& Putri, Y. (2021). The impact of social media access and anxiety among indonesia society during covid-19 outbreak. COUNS-EDU: The International Journal of Counseling and Education, 6(1). 1-10 DOI: http://dx.doi.org/ $10.23916 / 0020200528830$

\section{Introduction}

A novel coronavirus (CoV) is a new strain of coronavirus (Rota et al., 2003; Wu et al., 2020). A novel coronavirus (2019-nCoV) outbreak began in Wuhan, China, has been named corona virus disease 2019 (COVID-19) - 'CO' stands for corona, 'VI' for virus, and 'D' for disease (Acter et al., 2020; Zu et al., 2020). Formerly, this disease was referred to as '2019 novel coronavirus' or '2019-nCoV'. The COVID-19 virus is a new virus linked to the same family of viruses as Severe Acute Respiratory Syndrome (SARS) and some types of common cold (Peeri et al., 2020). The World Health Organization (WHO) has declared the 2019nCoV outbreak to be a Public Health Emergency of International Concern (PHEIC) (Zheng, 2020).

The coronavirus COVID-19 is affecting 213 countries and territories around the world until 15 May 2020. Five countries in the world with the most cases of Covid-19 are the United States, Spain, Russia, UK, and Italy. Indonesia became a country 34 with positive cases of COVID-19 in the world and a country with the most deaths cases in Southeast Asia (Organization, 2020). The first cases of COVID-19 was reported in Indonesia on 2 March 2020 in a number of two cases. The Ministry of Health the Republic Indonesia (Kemenkes) has declared the number of positive cases of COVID -19 on May 15, 2020, there were 16496 cases with 1076 deaths spreadout around Indonesia area (Tosepu et al., 2020). 


\section{COUNS-EDU}

Vol.6, No.1, 2021

Available online: http://journal.konselor.or.id/index.php/counsedu

Ifdil, I, et al.

This condition has a substantial psychological impact on individuals, the community, and medical personnel (Jin et al., 2020). The research included 1210 respondents from 194 cities in China the result show $53.8 \%$ of respondents rated the psychological impact of the outbreak as moderate or severe; $16.5 \%$ reported moderate to severe depressive symptoms; $28.8 \%$ reported moderate to severe anxiety symptoms; and $8.1 \%$ reported moderate to severe stress levels (Wang et al., 2020).

The development of the Covid-19 outbreak in Indonesia and the world dominated media coverage. It bases much information on social media about Corona Virus (COVID-19) which can affect mental health (Brennen, Simon, Howard, \& Nielsen, 2020). Social media use is complex. It is a source of entertainment, of connection, of information. It is also a reflection of what is on our minds. Forbes.com recently reported that in 1 day (February 28, 2020), 6.7 million people mentioned coronavirus on social media (Wiederhold, 2020). Less than 2 weeks later, on March 11, analytics company Sprinklr reported a record nearly 20 million mentions of coronavirus-related terms. The pandemic is most definitely what is on our minds (Wiederhold, 2020).

Following the development of the corona virus is important for vigilance. However, being exposed to information, both trusted and not, can also make someone anxious (Gao et al., 2020). Constant updates about coronavirus, especially those concerning confirmed cases and the number of deaths to date, can be extremely overwhelming and feel relentless. Moreover, rumors and speculation can add fuel to anxiety (Baines \& Elliott, 2020).

The exposure to media during a public crisis is partly responsible for the rise in mental health problems . Due to the uncertainty surrounding COVID-19 and the rapid development of news around the globe, social media users are bombarded with information on an almost constant basis (Wiederhold, 2020). The World Health Organization calls this an 'infodemic' and stresses the important task of dispelling rumors and misinformation (Baines \& Elliott, 2020; Cinelli et al., 2020) . Misinformation in a pandemic can negatively affect human health. Misinformation is false or inaccurate information deliberately intended to deceive (Bursztyn, Rao, Roth, \& Yanagizawa-Drott, 2020; Sharma et al., 2020). In the context of the current pandemic, it can greatly affect all aspects of life, especifically people's mental health, since searching for COVID-19 updates on the Internet has jumped 50\% - 70\% across all generations (Da Silva, 2020).Research on 4,872 adults from 31 different regions of China showed that $82 \%$ of respondents reported being frequently exposed to information about the pandemic through social media. Nearly half of respondents (48\%) made the cut off for depression and nearly a quarter $(23 \%)$ met criteria for anxiety. Around 19\% of respondents met criteria for both disorders (Gao, et al., 2020).

In Indonesian society the average time spent to access social media is 3 hours 26 minutes. The total active users of social media are 160 million or $59 \%$ of the total population of Indonesia. $99 \%$ of social media users surf via mobile (van der Wal, Arjadi, Nauta, Burger, \& Bockting, 2020). Many Indonesians access information about covid 19 through social media. The anxiety of the Indonesian people is exacerbated by the misinformation of social media. This research examines the impact of social media and anxiety among indonesian society during COVID-19.

\section{Method}

Study conducted to determine the impact using sosial media and anxiety among society during COVID-19 outbreak in Indonesia. This research uses snowball sampling technique. The instrument used in the study was the DASS semi-structured questionnaire changed by patients' anxiety. The procedure of this research is Indonesian citizens old were invited to participant online survey thought Survey Monkey platform. Links from instruments are sent via WhatsApp, e-mails, and other social media to the contact of the investigator. Research samples are requested to send surveys to many people. These links are sent to people separately from the first, and next contact points. Participants who have received and clicked on the link will be automatically directed to the information about the study and informed consent. After participants agree to complete the survey, participants are asked to fill in demographic details. Then, a series of sequential questions related to anxiety during the covid-19 pandemic must be answered by survey participants.

Data was collected from various regions in Indonesia. Then demographic aspects collected in this study are in the form of gender, age, internet access longtime, ethnicity, domicile, region, and the number 
of social media accounts. Anxiety aspects measured in this study comprised listening aspects, imagine aspects, watching / reading aspects. There are 1543 participant form aged 17 to 60 Year and form several province and region in Indonesia were involved in the current research. After participants completed answer questionnaires than data was analyzed using JASP (Jeffrey's Amazing Statistics Program).

\section{Result and Disscussion}

Table 1. Show that 1543 respondent anxiety forms 1001 in very haviness, 327 in Heaviness, 232 in Moderate, 1 in normal and 1 in wispy . In very haviness respondent with social media access $>6$ hours in a day experienced the highest anxiety with a frequency of 327 at a percentage of $32.7 \%$. Then respondents anxiety in Haviness when respondents access 3-4 hours in a day on social media with a frequency of 102 at $31.16 \%$. And respondents anxiety in moderate when access to social media 3-4 hours with a frequency of 68 at a percentage of $31.34 \%$. These results indicate that the COVID-19 outbreak caused anxiety conditions for the dominant Indonesian community in access to social media more than 6 hours.

Tabel 1. Anxiety Base on Social Media Access Frequencies for Access

\begin{tabular}{|c|c|c|c|c|c|}
\hline Anxiety & Access & Frequency & Percent & Valid Percent & Cumulative Percent \\
\hline \multirow{5}{*}{ Heaviness } & 1-2 Hour & 51 & 17.172 & 17.172 & 17.172 \\
\hline & 3-4 Hour & 80 & 26.936 & 26.936 & 44.108 \\
\hline & 5- 6 Hour & 46 & 15.488 & 15.488 & 59.596 \\
\hline & $>6$ Hour & 120 & 40.404 & 40.404 & 100.000 \\
\hline & Missing & 0 & 0.000 & & \\
\hline \multicolumn{2}{|l|}{ Total } & 297 & 100.000 & & \\
\hline \multirow[t]{5}{*}{ Moderate } & 1-2 Hour & 17 & 7.522 & 7.522 & 7.522 \\
\hline & 3-4 Hour & 64 & 28.319 & 28.319 & 35.841 \\
\hline & 5- 6 Hour & 78 & 34.513 & 34.513 & 70.354 \\
\hline & $>6$ Hour & 67 & 29.646 & 29.646 & 100.000 \\
\hline & Missing & 0 & 0.000 & & \\
\hline \multicolumn{2}{|l|}{ Total } & 226 & 100.000 & & \\
\hline \multirow{5}{*}{$\begin{array}{l}\text { Very } \\
\text { Heaviness }\end{array}$} & 1-2 Hour & 184 & 18.057 & 18.057 & 18.057 \\
\hline & 3-4 Hour & 328 & 32.188 & 32.188 & 50.245 \\
\hline & 5- 6 Hour & 220 & 21.590 & 21.590 & 71.835 \\
\hline & $>6$ Hour & 287 & 28.165 & 28.165 & 100.000 \\
\hline & Missing & 0 & 0.000 & & \\
\hline \multirow{2}{*}{ Total } & & 1019 & 100.000 & & \\
\hline & 1-2 Hour & 0 & 0.000 & 0.000 & 0.000 \\
\hline \multirow[t]{4}{*}{ Wispy } & 3-4 Hour & 1 & 100.000 & 100.000 & 100.000 \\
\hline & 5- 6 Hour & 0 & 0.000 & 0.000 & 100.000 \\
\hline & $>6$ Hour & 0 & 0.000 & 0.000 & 100.000 \\
\hline & Missing & 0 & 0.000 & & \\
\hline Total & & 1 & 100.000 & & \\
\hline
\end{tabular}

The Figures show that respondents anxiety in the very haviness category with the highest anxiety when the duration of social media access $>6$ hours in a day. Then in the Haviness category with a duration of 3-4 hours in a day. As well as in the Moderate category with a duration of 3-4 Hours in a day. Resopondent anxiety is very heavy when accessing social media about COVID-19 with a duration of $>6$ hours in a day. Then the anxiety of respondents in the category of heavy and moderate with social media duration 3-4 hours in a day. These results indicate that the longer the duration of respondents accessing social media regarding COVID-19 has an increasingly severe anxiety. 


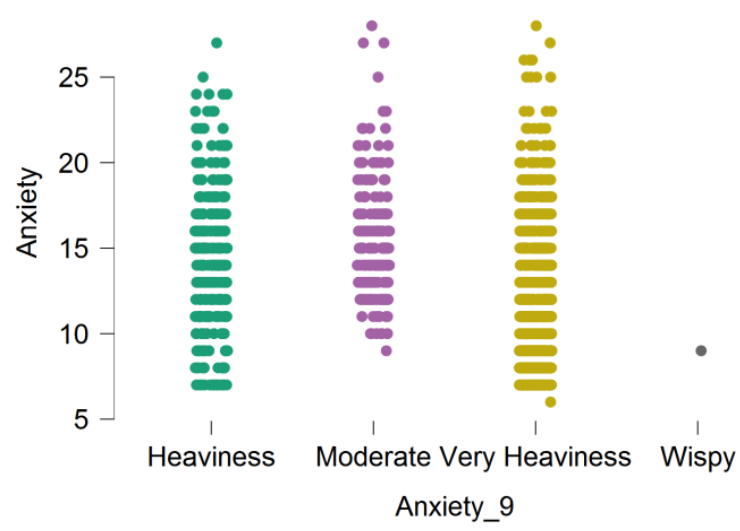

Figure 1. Anxiety Based on Category

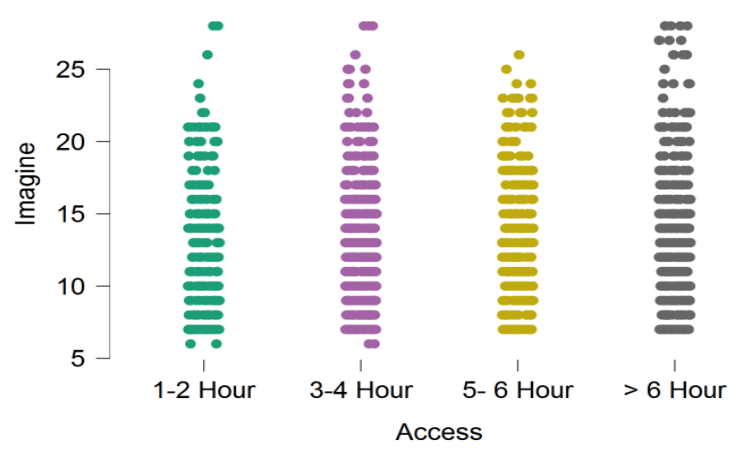

Figure 3. Imagine Aspect

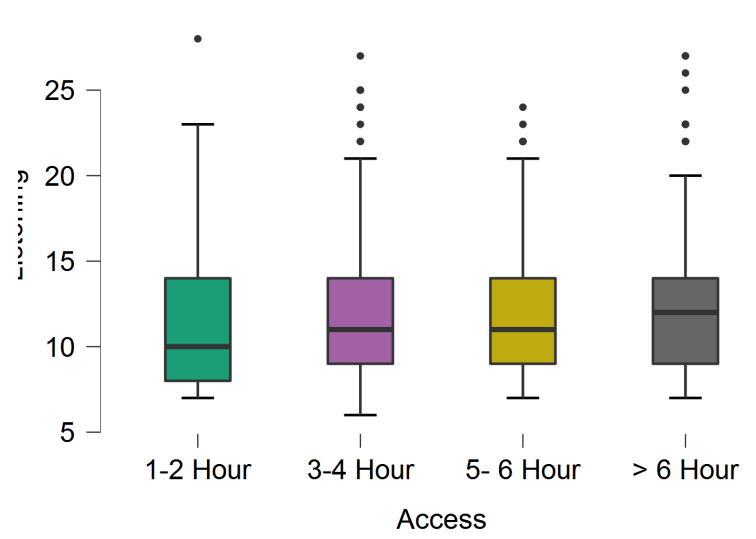

Figure 2. Listening Aspect

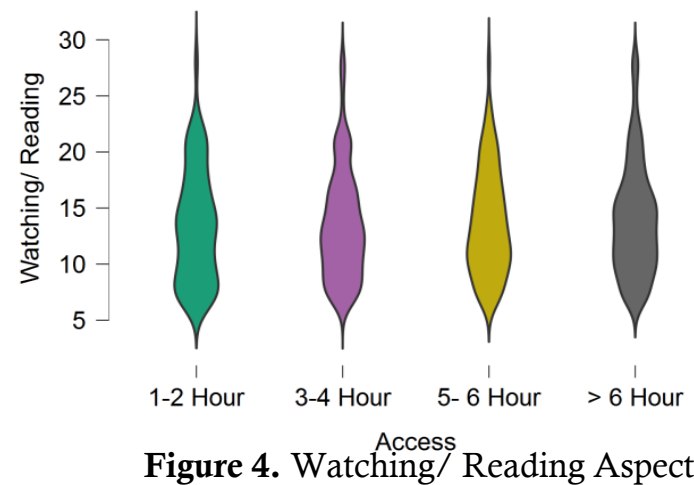

Social Media have played a large role in informing the public of health issues as well as shaping the public perception of those issues. In recent years, the numbers of people using social media, such as Facebook or Twitter, has increased, and the use of social media as an informational source for health can influence people's cognition or behavior related to health issues, including risk perceptions and preventive behaviors (Choi, Yoo, Noh, \& Park, 2017; W.-Y. Lin, Zhang, Song, \& Omori, 2016). The anxiety that occurs in certain areas is caused by "infodemik" (Gao et al., 2020), as well as negative and incorrect circulating in the community. In addition, anxiety in the midst of society is increasing due to the constant news dramatized by the media (Hoffman, 2020). Constant updates about coronavirus, especially those concerning confirmed cases and the number of deaths to date, can be extremely overwhelming and feel relentless. Moreover, rumors and speculation can add fuel to anxiety, which is why obtaining good quality information is so important (Nielsen, Fletcher, Newman, Brennen, \& Howard, 2020).

There are several aspects of respondents in accessing social media, by imagining, listening, watching/reading. Figure 4 shows that the respondents' anxiety is very heaviness that watching/reading have a higher anxiety with a percentage of $69.54 \%$, then Imagine with $63.64 \%$, and the lowest is listening with $55.02 \%$.

Tabel 3. Show that the anxiety level of Indonesian society higher when acess media sosial in watching/ reading rather then when imagine and listening information about COIVD-19. In watching/reading mean 12.9, imagine mean 13.6 listening mean 11,8. And in median 12,11,13. 
Tabel 2. Frequency Anxiety by Aspects of The Use Social Media

\begin{tabular}{|c|c|c|c|c|c|}
\hline$\overline{\text { Aspect }}$ & Category & Frequency & Percent & Valid Percent & Cumulative Percent \\
\hline \multirow[t]{6}{*}{ Imagine } & Heaviness & 260 & 16.850 & 16.85 & 16.850 \\
\hline & Moderate & 297 & 19.248 & 19.52 & 36.099 \\
\hline & Very Heaviness & 982 & 63.642 & 63.64 & 99.741 \\
\hline & Wispy & 4 & 0.259 & 0.26 & 100.000 \\
\hline & Missing & 0 & 0.000 & & \\
\hline & Total & 1543 & 100.000 & & \\
\hline \multirow[t]{6}{*}{ Listening } & Heaviness & 344 & 22.294 & 22.29 & 22.294 \\
\hline & Moderate & 349 & 22.618 & 22.62 & 44.913 \\
\hline & Very Heaviness & 849 & 55.023 & 55.02 & 99.935 \\
\hline & Wispy & 1 & 0.065 & 0.065 & 100.000 \\
\hline & Missing & 0 & 0.000 & & \\
\hline & Total & 1543 & 100.000 & & \\
\hline \multirow[t]{6}{*}{ Watching/ Reading } & Heaviness & 235 & 15.230 & 15.23 & 15.230 \\
\hline & Moderate & 233 & 15.100 & 15.10 & 30.331 \\
\hline & Very Heaviness & 1073 & 69.540 & 69.54 & 99.870 \\
\hline & Wispy & 2 & 0.130 & 0.130 & 100.000 \\
\hline & Missing & 0 & 0.000 & & \\
\hline & Total & 1543 & 100.000 & & \\
\hline
\end{tabular}

Tabel 3. Comparison Anxiety by Aspect

\begin{tabular}{lrrc}
\hline & \multicolumn{3}{c}{ Anxiety } \\
& \multicolumn{1}{c}{ Imagine } & Listening & Watching/ Reading \\
\hline Valid & 1543 & 1543 & 1543 \\
Missing & 0 & 0 & 0 \\
Mean & 12.9 & 11.8 & 13.6 \\
Median & 12 & 11 & 13 \\
Std. Deviation & 4.647 & 3.797 & 4.874 \\
Variance & 21.6 & 14.4 & 23.7 \\
Minimum & 6. & 6. & 6. \\
Maximum & 28. & 28. & 28. \\
\hline
\end{tabular}

Figure 4. Show the anxiety base of aspect in watching/reading have a higher, then Imagine and listening. These results indicate that the COVID-19 outbreak caused anxiety conditions for the dominant Indonesian community is when they watching/ reading information about COVID-19 on social media.

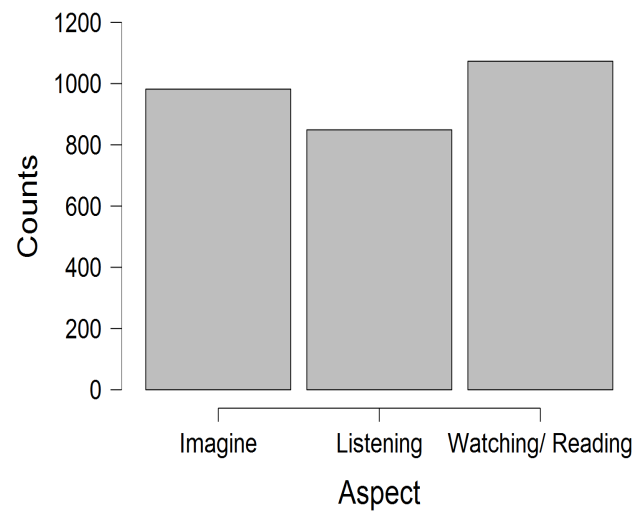

Figure 5. Anxiety by the Aspect

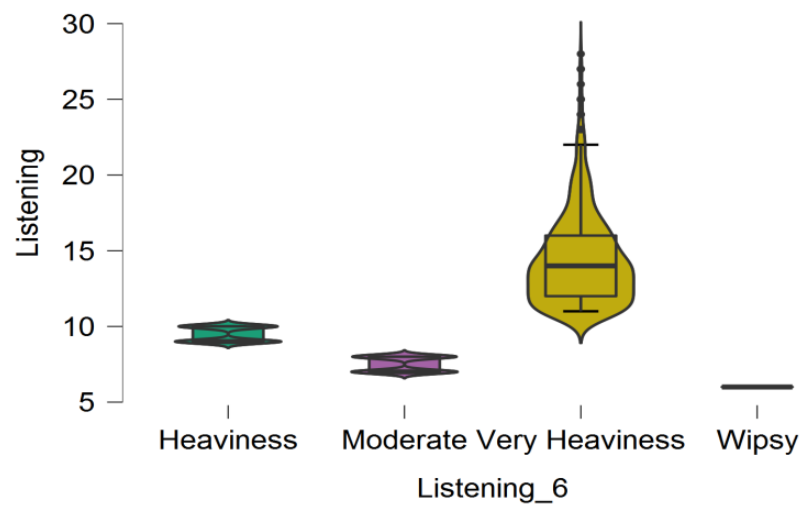

Figure 6. Listening Aspect 


\section{COUNS-EDU}

Vol.6, No.1, 2021

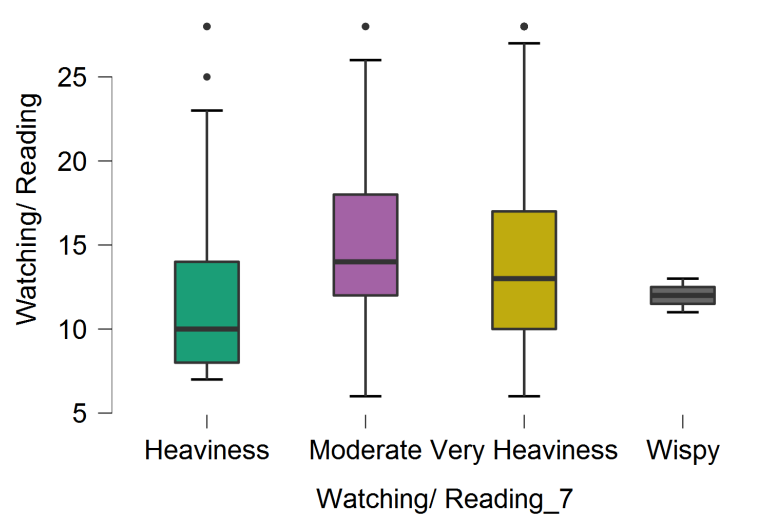

Figure 7. Watching/Reading Aspect

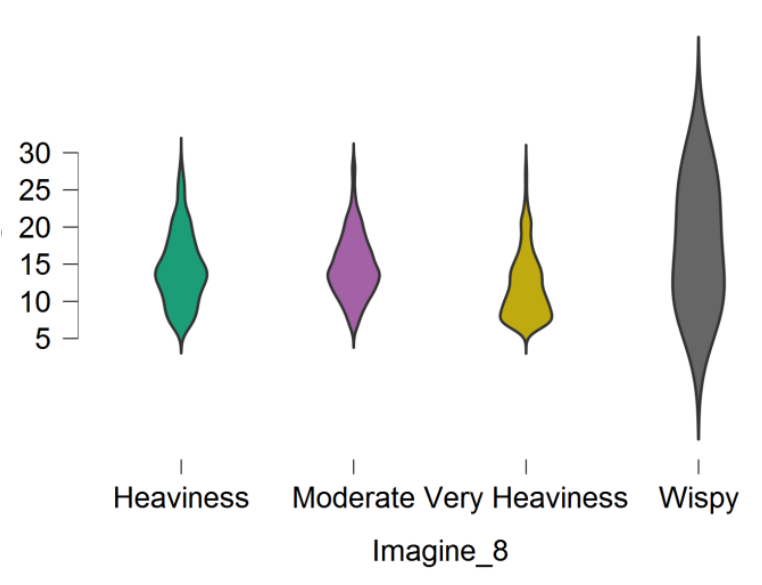

Figure 8. Watching/Reading Aspect

Base the result that responden in very heaviness anxiety when they aceess social media more than 6 hour in a day because during COVID-19 outbreak, disinformation and false reports about the COVID-19 have bombarded social media and stoked unfounded fears among many netizens. many citizens expressed their negative feelings, such as fear, worry, nervous, anxiety (Stankovska, Memedi, \& Dimitrovski, 2020). During disease outbreaks, community anxiety can rise following the increased media reporting.

The World Health Organization dubbed the new coronavirus "a massive 'infodemic," referring to "an overabundance of information - some accurate and some not. all caused global panic, fears around the coronavirus have been especially amplified by social media. It has allowed disinformation to spread and flourish at unprecedented speeds, creating an environment of heightened uncertainty that has fueled anxiety and racism in person and online. In Indonesia The Ministry of Communication and Information (Menkominfo) detected more than 1,125 hoax news or incorrect information that was spread amid the Corona virus pandemic (COVID-19). The hoax is spread across 1209 digital platforms, such as Facebook, Instagram, Twitter and YouTube.

Frightening information about COVID-19 also makes people worried (Jackson et al., 2020; C.-Y. Lin, 2020; Nicomedes \& Avila, 2020; Roy et al., 2020; Sorokowski et al., 2020). The condition has an impact on one's immunity in the middle of the Corona pandemic (D'Antiga, 2020; X. Li, Geng, Peng, Meng, \& Lu, 2020). Anxiety and fear affect brain regions (Bremner, 2004; Moulédous, Roullet, \& Guiard, 2018; Nitschke, Heller, \& Miller, 2000). These anxiety and fear affect brain regions, including the amygdala (Fox \& Shackman, 2019; K.-X. Li et al., 2019; Shackman \& Fox, 2016), ventromedial hypothalamus (Jiang et al., 2018), hippocampus (Calıșkan \& Stork, 2019; Rigoli, Ewbank, Dalgleish, \& Calder, 2016; Robertson et al., 2017; Villasana, Weber, Akinyeke, \& Raber, 2016), nucleus accumbens (Burkhouse et al., 2019; Günther et al., 2018; Yamada et al., 2020), BNST (terminal stria nucleus nucleus) (Donner et al., 2020; Mazzone et al., 2018; Yamauchi et al., 2018), inframlimbic cortex (between various parts of the prefrontal cortex) (Berg, Eckardt, \& Masseck, 2019; Koppensteiner et al., 2019), and insular cortex (Gogolla, 2017; T.-Y. Shi et al., 2018; T. Shi, Feng, Wei, \& Zhou, 2020; Yeung et al., 2019). This brain region is a neural network that mediates learning (Chen et al., 2019; Daniel-Robert, Schneider, \& Maurice, 2020; Lindström, Haaker, \& Olsson, 2018) and emotional behavior (Pessoa, 2018). It plays a major role in mediating fear and other emotions (Cai, Wang, Paulucci-Holthauzen, \& Pan, 2018). Common symptoms of anxiety include sleep problems (Peterman et al., 2016), panic attactk, anxiety, tension, nervousness (Bandelow, Michaelis, \& Wedekind, 2017).

Reserach finding respondents' anxiety is very heaviness when watching/reading information about COVID-19. Social media use is complex reading or watching lots of news about coronavirus has led to anxiety (Council, 2020). Information processing mode can also influence individuals' risk perceptions. When people access information regarding public health-risk issues, their risk perception is shaped and/or changed by how they process risk-related information (Choi, et al., 2017). Indoensian society are the most anxious about the Coronavirus are those who are consuming the most news from social media,. The more anxious 
feel, the more indonesian society should distance from the media. And if responden are extremely fearful, stop watching and reading alltogether.

Strategis to reducing anxiety is minimize watching, reading, imagine, or listening to news about COVID-19 that causes to feel anxious or distressed; seek information only from trusted sources and mainly so that you can take practical steps to prepare your plans and protect yourself and loved ones. Seek information updates at specific times during the day, once or twice. The sudden and near-constant stream of news reports about an outbreak can cause anyone to feel worried. Get the facts; not rumours and misinformation. Gather information at regular intervals from the WHO website and local health authority platforms in order to help you distinguish facts from rumours (Pulido, Villarejo-Carballido, Redondo-Sama, \& Gómez, 2020; Zarocostas, 2020).

Share simple facts about what is going on and give clear information about how to reduce risk of infection in words older people with/without cognitive impairment can understand. Repeat the information whenever necessary. Instructions need to be communicated in a clear, concise, respectful and patient way. It may also be helpful for information to be displayed in writing or Figures. Engage family members and other support networks in providing information and helping people to practise prevention measures (Tavoschi et al., 2020).

\section{Conclusions}

The findings of the research showed that the anxiety level of Indonesian society higher when access social media more than 6 hour. the longer the duration of respondents accessing social media regarding COVID-19 has an increasingly severe anxiety. aspects of respondents in accessing social media, by imagining, listening, watching / reading. Figure 4 shows that the respondents' anxiety is very heaviness that watching/reading have a higher anxiety with a percentage of $69.54 \%$, then Imagine with $63.64 \%$, and the lowest is listening with $55.02 \%$. These findings implicate the Indonesian society need pay more attention to minimize watching, reading or listening to news about COVID-19 that causes to feel anxious and seek information only from trusted sources. Stay informed by sticking to trusted sources of information such as government. Implicated the government attention to mental health among general populationwhile combating with COVID-19. Goverment combat with "infodemic" by monitoring and filtering out false information and promoting accurate information though cross-section collaborations.

\section{References}

Acter, T., Uddin, N., Das, J., Akhter, A., Choudhury, T. R., \& Kim, S. (2020). Evolution of severe acute respiratory syndrome coronavirus 2 (SARS-CoV-2) as coronavirus disease 2019 (COVID-19) pandemic: A global health emergency. Science of the Total Environment, 138996.

Baines, D., \& Elliott, R. J. (2020). Defining misinformation, disinformation and malinformation: An urgent need for clarity during the COVID-19 infodemic.

Bandelow, B., Michaelis, S., \& Wedekind, D. (2017). Treatment of anxiety disorders. Dialogues in clinical neuroscience, 19(2), 93.

Berg, L., Eckardt, J., \& Masseck, O. A. (2019). Enhanced activity of pyramidal neurons in the infralimbic cortex drives anxiety behavior. PLoS ONE, 14(1).

Bremner, J. D. (2004). Brain imaging in anxiety disorders. Expert Review of Neurotherapeutics, 4(2), 275-284.

Brennen, J. S., Simon, F., Howard, P. N., \& Nielsen, R. K. (2020). Types, sources, and claims of COVID19 misinformation. Reuters Institute, 7.

Burkhouse, K. L., Jimmy, J., Defelice, N., Klumpp, H., Ajilore, O., Hosseini, B., et al. (2019). Nucleus accumbens volume as a predictor of anxiety symptom improvement following CBT and SSRI treatment in two independent samples. Neuropsychopharmacology, 1-9.

Bursztyn, L., Rao, A., Roth, C., \& Yanagizawa-Drott, D. (2020). Misinformation during a pandemic. University of Chicago, Becker Friedman Institute for Economics Working Paper(2020-44).

Cai, Y.-Q., Wang, W., Paulucci-Holthauzen, A., \& Pan, Z. Z. (2018). Brain circuits mediating opposing effects on emotion and pain. Journal of Neuroscience, 38(28), 6340-6349.

Çalışkan, G., \& Stork, O. (2019). Hippocampal network oscillations at the interplay between innate anxiety and learned fear. Psychopharmacology, 236(1), 321-338. 
Chen, Y., Qi, D., Qin, T., Chen, K., Ai, M., Li, X., et al. (2019). Brain network connectivity mediates education-related cognitive performance in healthy elderly adults. Current Alzheimer Research, 16(1), 1928.

Choi, D.-H., Yoo, W., Noh, G.-Y., \& Park, K. (2017). The impact of social media on risk perceptions during the MERS outbreak in South Korea. Computers in Human Behavior, 72, 422-431.

Cinelli, M., Quattrociocchi, W., Galeazzi, A., Valensise, C. M., Brugnoli, E., Schmidt, A. L., et al. (2020). The covid-19 social media infodemic. arXiv preprint arXiv:2003.05004.

Council, K. (2020). Kirklees Local Offer resources for the coronavirus outbreak.

D'Antiga, L. (2020). Coronaviruses and immunosuppressed patients: the facts during the third epidemic. Liver Transplantation.

Da Silva, E. (2020). Mental Health and Online Information During the COVID-19 Pandemic. InterAmerican Journal of Medicine and Health, 3.

Daniel-Robert, C., Schneider, F. C., \& Maurice, P. (2020). Neural Networks Mediating Perceptual Learning in Congenital Blindness. Scientific Reports (Nature Publisher Group), 10(1).

Donner, N. C., Davies, S. M., Fitz, S. D., Kienzle, D. M., Shekhar, A., \& Lowry, C. A. (2020). Crh receptor priming in the bed nucleus of the stria terminalis (BNST) induces tph2 gene expression in the dorsomedial dorsal raphe nucleus and chronic anxiety. Progress in Neuro-Psychopharmacology and Biological Psychiatry, 96, 109730.

Fox, A. S., \& Shackman, A. J. (2019). The central extended amygdala in fear and anxiety: Closing the gap between mechanistic and neuroimaging research. Neuroscience letters, 693, 58-67.

Gao, J., Zheng, P., Jia, Y., Chen, H., Mao, Y., Chen, S., et al. (2020). Mental health problems and social media exposure during COVID-19 outbreak. Plos one, 15(4), e0231924.

Gogolla, N. (2017). The insular cortex. Current Biology, 27(12), R580-R586.

Günther, V., Ihme, K., Kersting, A., Hoffmann, K.-T., Lobsien, D., \& Suslow, T. (2018). Volumetric associations between amygdala, nucleus accumbens, and socially anxious tendencies in healthy women. Neuroscience, 374, 25-32.

Hoffman, A. (2020). The Securitization of the Coronavirus Crisis in the Middle East. The COVID-19 Pandemic in the Middle East and North Africa, 10.

Jackson, D., Bradbury-Jones, C., Baptiste, D., Gelling, L., Morin, K., Neville, S., et al. (2020). Life in the pandemic: some reflections on nursing in the context of COVID-19. Journal of Clinical Nursing.

Jiang, J. H., Peng, Y. L., Zhang, P. J., Xue, H. X., He, Z., Liang, X. Y., et al. (2018). The ventromedial hypothalamic nucleus plays an important role in anxiolytic-like effect of neuropeptide S. Neuropeptides, 67, 36-44.

Jin, X., Lian, J.-S., Hu, J.-H., Gao, J., Zheng, L., Zhang, Y.-M., et al. (2020). Epidemiological, clinical and virological characteristics of 74 cases of coronavirus-infected disease 2019 (COVID-19) with gastrointestinal symptoms. Gut, 69(6), 1002-1009.

Koppensteiner, P., Von Itter, R., Melani, R., Galvin, C., Lee, F. S., \& Ninan, I. (2019). Diminished fear extinction in adolescents is associated with an altered somatostatin interneuron-mediated inhibition in the infralimbic cortex. Biological Psychiatry, 86(9), 682-692.

Li, K.-X., He, M., Ye, W., Simms, J., Gill, M., Xiang, X., et al. (2019). TMEM16B regulates anxiety-related behavior and GABAergic neuronal signaling in the central lateral amygdala. eLife, 8 .

Li, X., Geng, M., Peng, Y., Meng, L., \& Lu, S. (2020). Molecular immune pathogenesis and diagnosis of COVID-19. Journal of Pharmaceutical Analysis.

Lin, C.-Y. (2020). Social reaction toward the 2019 novel coronavirus (COVID-19). Social Health and Behavior, $3(1), 1$.

Lin, W.-Y., Zhang, X., Song, H., \& Omori, K. (2016). Health information seeking in the Web 2.0 age: Trust in social media, uncertainty reduction, and self-disclosure. Computers in Human Behavior, 56, 289-294.

Lindström, B., Haaker, J., \& Olsson, A. (2018). A common neural network differentially mediates direct and social fear learning. NeuroImage, 167, 121-129.

Mazzone, C. M., Pati, D., Michaelides, M., DiBerto, J., Fox, J. H., Tipton, G., et al. (2018). Acute engagement of $\mathrm{G}$ q-mediated signaling in the bed nucleus of the stria terminalis induces anxiety-like behavior. Molecular psychiatry, 23(1), 143-153.

Moulédous, L., Roullet, P., \& Guiard, B. P. (2018). Brain Circuits Regulated by the 5-HT 2A Receptor: Behavioural Consequences on Anxiety and Fear Memory 5-HT2A Receptors in the Central Nervous System (pp. 231-258): Springer. 
Nicomedes, C., \& Avila, R. (2020). An Analysis on the Panic of Filipinos During COVID-19 Pandemic in the Philippines: DOI.

Nielsen, R. K., Fletcher, R., Newman, N., Brennen, J. S., \& Howard, P. N. (2020). Navigating the 'Infodemic': How People in Six Countries Access and Rate News and Information about Coronavirus. Misinformation, science, and media, 2020-2004.

Nitschke, J. B., Heller, W., \& Miller, G. A. (2000). Anxiety, stress, and cortical brain function. The neuropsychology of emotion, 1, 298-219.

Organization, W. H. (2020). Coronavirus disease 2019 ( COVID-19): situation report, 92.

Peeri, N. C., Shrestha, N., Rahman, M. S., Zaki, R., Tan, Z., Bibi, S., et al. (2020). The SARS, MERS and novel coronavirus (COVID-19) epidemics, the newest and biggest global health threats: what lessons have we learned? International journal of epidemiology.

Pessoa, L. (2018). Understanding emotion with brain networks. Current opinion in behavioral sciences, 19, 1925.

Peterman, J. S., Carper, M. M., Elkins, R. M., Comer, J. S., Pincus, D. B., \& Kendall, P. C. (2016). The effects of cognitive-behavioral therapy for youth anxiety on sleep problems. Journal of anxiety disorders, 37, 78-88.

Pulido, C. M., Villarejo-Carballido, B., Redondo-Sama, G., \& Gómez, A. (2020). COVID-19 infodemic: More retweets for science-based information on coronavirus than for false information. International Sociology, 0268580920914755.

Rigoli, F., Ewbank, M., Dalgleish, T., \& Calder, A. (2016). Threat visibility modulates the defensive brain circuit underlying fear and anxiety. Neuroscience letters, 612, 7-13.

Robertson, J. M., Achua, J. K., Smith, J. P., Prince, M. A., Staton, C. D., Ronan, P. J., et al. (2017). Anxious behavior induces elevated hippocampal Cb2 receptor gene expression. Neuroscience, 352, $273-$ 284.

Rota, P. A., Oberste, M. S., Monroe, S. S., Nix, W. A., Campagnoli, R., Icenogle, J. P., et al. (2003). Characterization of a novel coronavirus associated with severe acute respiratory syndrome. science, 300(5624), 1394-1399.

Roy, D., Tripathy, S., Kar, S. K., Sharma, N., Verma, S. K., \& Kaushal, V. (2020). Study of knowledge, attitude, anxiety \& perceived mental healthcare need in Indian population during COVID-19 pandemic. Asian journal of psychiatry, 102083.

Shackman, A. J., \& Fox, A. S. (2016). Contributions of the central extended amygdala to fear and anxietycontributions of the central extended amygdala to fear and anxiety. Journal of Neuroscience, 36(31), 8050-8063.

Sharma, K., Seo, S., Meng, C., Rambhatla, S., Dua, A., \& Liu, Y. (2020). Coronavirus on social media: Analyzing misinformation in Twitter conversations. arXiv preprint arXiv:2003.12309.

Shi, T.-Y., Feng, S.-F., Wei, M.-X., Huang, Y., Liu, G., Wu, H.-T., et al. (2018). Kainate receptor mediated presynaptic LTP in agranular insular cortex contributes to fear and anxiety in mice. Neuropharmacology, $128,388-400$.

Shi, T., Feng, S., Wei, M., \& Zhou, W. (2020). Role of the anterior agranular insular cortex in the modulation of fear and anxiety. Brain Research Bulletin, 155, 174-183.

Sorokowski, P., Groyecka, A., Kowal, M., Sorokowska, A., Białek, M., Lebuda, I., et al. (2020). Information about pandemic increases negative attitudes toward foreign groups: a case of COVID-19 outbreak.

Stankovska, G., Memedi, I., \& Dimitrovski, D. (2020). Coronavirus COVID-19 disease, mental health and psychosocial support. Society Register, 4(2), 33-48.

Tavoschi, L., Quattrone, F., D’Andrea, E., Ducange, P., Vabanesi, M., Marcelloni, F., et al. (2020). Twitter as a sentinel tool to monitor public opinion on vaccination: an opinion mining analysis from September 2016 to August 2017 in Italy. Human Vaccines \& Immunotherapeutics, 1-8.

Tosepu, R., Gunawan, J., Effendy, D. S., Lestari, H., Bahar, H., \& Asfian, P. (2020). Correlation between weather and Covid-19 pandemic in Jakarta, Indonesia. Science of the Total Environment, 138436.

van der Wal, J. M., Arjadi, R., Nauta, M. H., Burger, H., \& Bockting, C. L. (2020). Guided internet interventions for depression: Impact of sociodemographic factors on treatment outcome in Indonesia. Behaviour research and therapy, 103589.

Villasana, L. E., Weber, S., Akinyeke, T., \& Raber, J. (2016). Genotype differences in anxiety and fear learning and memory of WT and ApoE4 mice associated with enhanced generation of hippocampal reactive oxygen species. Journal of neurochemistry, 138(6), 896-908. 
Wang, C., Pan, R., Wan, X., Tan, Y., Xu, L., Ho, C. S., et al. (2020). Immediate psychological responses and associated factors during the initial stage of the 2019 coronavirus disease (COVID-19) epidemic among the general population in China. International journal of environmental research and public health, $17(5), 1729$.

Wiederhold, B. K. (2020). Using social media to our advantage: Alleviating anxiety during a pandemic. Cyberpsychology, Behavior, and Social Networking, 23(4), 197-198.

Wu, A., Peng, Y., Huang, B., Ding, X., Wang, X., Niu, P., et al. (2020). Genome composition and divergence of the novel coronavirus (2019-nCoV) originating in China. Cell host \& microbe.

Yamada, S., Islam, M. S., van Kooten, N., Bovee, S., Oh, Y.-M., Tsujimura, A., et al. (2020). Neuropeptide $\mathrm{Y}$ neurons in the nucleus accumbens modulate anxiety-like behavior. Experimental Neurology, 327, 113216.

Yamauchi, N., Takahashi, D., Sugimura, Y. K., Kato, F., Amano, T., \& Minami, M. (2018). Activation of the neural pathway from the dorsolateral bed nucleus of the stria terminalis to the central amygdala induces anxiety-like behaviors. European Journal of Neuroscience, 48(9), 3052-3061.

Yeung, A. W. K., Lee, J. C. M., Tanabe, H. C., Ng, S. K. S., Khong, P.-L., Leung, W. K., et al. (2019). Short version Dental Anxiety Inventory score may predict the response in the insular cortex to stimuli mimicking dental treatment. Frontiers in human neuroscience, 13, 204.

Zarocostas, J. (2020). How to fight an infodemic. The Lancet, 395(10225), 676.

Zheng, W. (2020). Mental health and a novel coronavirus (2019-nCoV) in China. Journal of affective disorders, 269, 201.

Zu, Z. Y., Jiang, M. D., Xu, P. P., Chen, W., Ni, Q. Q., Lu, G. M., et al. (2020). Coronavirus disease 2019 (COVID-19): a perspective from China. Radiology, 200490. 